\title{
Correction to: Transnational law as a framework for law clinics
}

\author{
Sital Kalantry ${ }^{1} \cdot$ Rachael Hancock $^{2}$
}

Accepted: 27 February 2021 / Published online: 8 March 2021

(c) O.P. Jindal Global University (JGU) 2021

\section{Correction to: Jindal Global Law Review https://doi.org/10.1007/s41020-020-00124-3}

The article Transnational law as a framework for law clinics, written by Sital Kalantry and Rachael Hancock, was originally published online on the publisher's internet portal on February 20, 2021 with Open Access under Creative Commons Attribution 4.0 International License, which permits use, sharing, adaptation, distribution and reproduction in any medium or format, as long as you give appropriate credit to the original author(s) and the source, provide a link to the Creative Commons licence, and indicate if changes were made. The images or other third party material in this article are included in the article's Creative Commons licence, unless indicated otherwise in a credit line to the material. If material is not included in the article's Creative Commons licence and your intended use is not permitted by statutory regulation or exceeds the permitted use, you will need to obtain permission directly from the copyright holder. To view a copy of this licence, visit http:// creativecommons.org/licenses/by/4.0/. With the author's/authors' decision to cancel Open Access the copyright of the article changed on March 3, 2021 to (C) O.P. Jindal Global University (JGU) 2021 with all rights reserved.

Publisher's Note Springer Nature remains neutral with regard to jurisdictional claims in published maps and institutional affiliations.

The original article can be found online at https://doi.org/10.1007/s41020-020-00124-3.

Sital Kalantry

skalantry@cornell.edu

Rachael Hancock

reh284@cornell.edu

1 Cornell Law School, Ithaca, USA

2 United States District Court for the District of New Jersey, Camden, USA 